\begin{tabular}{|c|l|}
\hline Title & $\begin{array}{l}\text { Mutagenicity of alkylhydrazine oxalates in salmonella typhimurium TA100 and TA102 } \\
\text { demonstrated by modifying the growth conditions of the bacteria }\end{array}$ \\
\hline Sub Title & \multicolumn{1}{|c|}{} \\
\hline Author & $\begin{array}{l}\text { 松下, 洋久(Matsushita, Hirohisa) } \\
\text { 遠藤, 治(Endo, Osamu) } \\
\text { 松下, 秀鶴(Matsushita, Hidetsuru) } \\
\text { 山本, 雅子(Yamamoto, Masako) } \\
\text { 望月, 正隆(Mochizuki, Masataka) }\end{array}$ \\
\hline Publisher & 共立薬科大学 \\
\hline Publication year & 1993 \\
\hline Jtitle & $\begin{array}{l}\text { 共立薬科大学研究年報 (The annual report of the Kyoritsu College of } \\
\text { Pharmacy). No.38 (1993. ),p.73- 73 }\end{array}$ \\
\hline JaLC DOI & \\
\hline Abstract & \\
\hline Notes & 抄録 \\
\hline Genre & Technical Report \\
\hline URL & $\begin{array}{l}\text { https://koara.lib.keio.ac.jp/xoonips/modules/xoonips/detail.php?koara_id=AN00062898-0000003 } \\
8-0073\end{array}$ \\
\hline
\end{tabular}

慶應義塾大学学術情報リポジトリ(KOARA)に揭載されているコンテンツの著作権は、それぞれの著作者、学会または出版社/発行者に帰属し、その権利は著作権法によって 保護されています。引用にあたっては、著作権法を遵守してご利用ください。

The copyrights of content available on the KeiO Associated Repository of Academic resources (KOARA) belong to the respective authors, academic societies, or publishers/issuers, and these rights are protected by the Japanese Copyright Act. When quoting the content, please follow the Japanese copyright act. 
No. 38 (1993)

\title{
Mutagenicity of Alkylhydrazine Oxalates in Salmonella typhimurium TA 100 and TA 102 Demonstrated by Modifying the Growth Conditions of the Bacteria
}

\author{
Hirohisa Matsushita Jr., Osamu Endo**, Hidetsuru Matsushita**, \\ Masako Yамамото and Masataka MochizuKI \\ 松下洋久, 遠藤 治**, 松下秀鶴**, 山本雅子, 望月正隆
}

\begin{abstract}
Alkylhydrazines are important carcinogens. However, they show generally only weak mutagenicity and the activities reported from different laboratories are contradictory. We have developed a sensitive method to detect the mutagenicity of alkylhydrazines. The method is based on a modified preculturing procedure in the Ames test, the emphasis in the modification being a change in the growth period of tester strains. The optimal growth periods were found to be $11 \mathrm{~h}$ in Salmonella typhimurium TA 100 and $5 \mathrm{~h}$ in Salmonella typhimurium TA 102. We tested the mutagenic activity of 12 alkylhydrazines; 1,2-dimethylhydrazine, 1,2-diethylhydrazine, 1,2-dipropylhydrazine, 1,2-dibutylhydrazine, 1,1-dimethylhydrazine, 1,1-diethylhydrazine, 1,1-dipropylhydrazine, 1,1-dibutylhydrazine, methylhydrazine, ethylhydrazine, propylhydrazine, and butylhydrazine. All 12 alkylhydrazines were clearly mutagenic in Salmonella typhimurium TA 102, and 10 hydrazines were mutagenic in Salmonella typhimurium TA 100, both in the absence of S9 mix. The mutagenicity was inhibited by the addition of S9 mix or bovine serum albumin. This suggests deactivation of the mutagens by proteins.
\end{abstract}

* 本報告は Mutation Res., 301, 213-222（1993）に発表。

** 国立公衆衛生院 